\title{
Factors influencing Al-Cu weld properties by intermetallic compound formation
}

\author{
Paul Kah*, Cyril Vimalraj, Jukka Martikainen and Raimo Suoranta
}

\begin{abstract}
Dissimilar welding of aluminium (Al) and copper (Cu) has many applications in the electric power, electronic and piping industries. The weldments in these applications are highly valued for their corrosion resistance, heat and electricity conducting properties. The Al-Cu joints are lighter, cheaper and have conductivity equal to that of copper alloys. Much research has investigated dissimilar welding of Al-Cu by solid-state welding and fusion welding processes with the aim of optimising the properties and strength of such dissimilar joints. The main aim of the study is to critically review the factors influencing the properties of the Al-Cu joint. The study mainly discusses about the effects of intermetallic compounds (IMC) on the properties of Al-Cu joint and their effect while in service. The effects of joining aluminium alloy 1060 with pure copper by laser welding, friction stir welding and brazing have been reviewed and compared. The review shows that the various intermetallic compound formations in the joint have both beneficial and detrimental effects. The characteristics of these intermetallic compounds vary according to the location of the phase formed. Comparison of processes and parameters for welding of Al 1060 with pure Cu shows that the formation of the intermetallic compounds and their effects on the weld properties are mainly influenced by the welding speed, heat input, the thermal properties of the base metals and the filler metal as well as the dilution between the base metal and filler metal.
\end{abstract}

Keywords: Dissimilar welding; Aluminium; Copper; Factors influencing the Al-Cu joint; Intermetallic compounds; CuAl 2 ; $\mathrm{Cu}_{9} \mathrm{Al}_{4} ; \mathrm{CuAl}$

\section{Review}

Introduction

Many industries such as the marine, aerospace, petrochemical and automobile industries have recognised the potential of dissimilar welding of metals to provide safe structures that can operate in fluctuating service conditions while at the same time offering manufacturing cost savings. For instance, $\mathrm{Al}-\mathrm{Cu}$ joints are used as electrical connectors in many industries because of their good corrosion resistance and electrical conductivity (Klauke, 2012; Feng et al. 2012a). However, the mechanical properties of $\mathrm{Al}-\mathrm{Cu}$ joints can be reduced by brittle intermetallic compound phases formed during welding. To reduce these brittle intermetallic compounds in the joint, addition processing is required, which increases the manufacturing cost.

\footnotetext{
* Correspondence: paul.kah@lut.fi

Laboratory of Welding Technology, Lappeenranta University of Technology, FI 53851, Lappeenranta, Finland
}

$\mathrm{Al}-\mathrm{Cu}$ joints are difficult to manufacture by fusion welding processes due to the significant difference in the chemical composition and physical properties of the base metals. Consequently, these type of dissimilar joints are mostly welded by solid-state welding processes, where only the differences in the physical and mechanical properties of the base metals need to be considered (Joseph 2006). With fusion welding processes, on the other hand, many more factors have to be considered, such as the dilution of the filler metal and base metals, the physical properties of the base metals and filler metal and the heat treatment used.

Previous studies have shown oxide layer formation on the weld $\mathrm{Al}$ substrate in $\mathrm{Al}-\mathrm{Cu}$ joints manufactured with fusion welding, which results in insufficient bonding and ineffective electrical properties (Lloyd 1957). This phenomenon of incomplete fusion in the joint caused by oxide formation has also been noted in friction welding (Ochi, et al., 2004). Another problem found in welding $\mathrm{Al}$ and $\mathrm{Cu}$ is that mutual solubility between $\mathrm{Al}$ and

\section{实 Springer}


$\mathrm{Cu}$ occurs in the liquid state but brittle intermetallic compounds form after solidification, resulting in degradation of the weld properties (Weigl \& Schmidt, 2009). These brittle intermetallic compounds can initiate cracks, due to the significant difference in melting temperature, thermal conductivity and thermal expansion of the base metals, migration of the elements and the microstructural gradient (Sun \& Karppi, 1996; Posinasetti and Prasad 2005; Joseph 2006; Ihor \& Schmidt, 2006). Although fusion and solid-state welding processes encounter slightly different challenges in welding $\mathrm{Al}$ and $\mathrm{Cu}$, the major problem common to both welding processes is brittle intermetallic compound formations in the joint.

From the point of view of in-service life, oxide formation poses considerable difficulties. When the joint is exposed to the environment, Al easily oxidises, which results in resistance to the electric current flow. Moreover, the brittle intermetallic compounds grow while in service, degrading the weld properties. Brittle intermetallic compounds can be avoided by utilising the phase diagram of $\mathrm{Al}$ and $\mathrm{Cu}$ to select appropriate welding processes and parameters and suitable filler metals and by controlling the dilution effect between the base metals and filler metals. Hence, to reduce manufacturing costs, there is a need to examine further factors that influence intermetallic compound formation and its effect on the joint.

The paper focuses on the factors that influence $\mathrm{Al}-\mathrm{Cu}$ joint properties, in particular intermetallic compound formation during welding and while in service. To get a more comprehensive picture of the weld properties of $\mathrm{Al}-\mathrm{Cu}$ dissimilar joints, the study compares intermetallic compound formation in welding of $\mathrm{Al}$ (1060) with pure $\mathrm{Cu}$ by high energy density welding processes, solid-state welding processes and brazing techniques.

\section{Factors influencing the $\mathrm{Al}-\mathrm{Cu}$ weld properties}

$\mathrm{Al}-\mathrm{Cu}$ weld properties depend on the microstructure formed in the weld metal and along the adjacent sides of the weld seam. Moreover, the intermetallic compound phases formed in the microstructure have a major influence in the weld properties.

\section{Influence of the dilution between the base metals}

Improper dilution (i.e. solubility) between the metals welded influences the microstructural formations and thus affects the mechanical properties of the weld metal (Joseph 2006). From the phase diagram as shown in Fig. 1, it can be seen that the maximum solubility of $\mathrm{Cu}$ to $\mathrm{Al}$ for a solid solution is only $5.65 \mathrm{wt} . \%$ of $\mathrm{Cu}$ (Mai and Spowage 2004). Consequently, a joint formed by friction welding can have brittle intermetallic compounds (i.e. $\mathrm{CuAl}_{2}, \mathrm{CuAl}$ and $\mathrm{Cu}_{9} \mathrm{Al}_{4}$ ) along the transition region of the $\mathrm{Cu}$ due to inappropriate dilution between the $\mathrm{Al}$ and $\mathrm{Cu}$. These brittle intermetallic compounds reduce the mechanical properties of the joint (Sahin, 2009).

Defects are also formed along the $\mathrm{Al}-\mathrm{Cu}$ joint due to improper dilution between the base metals and filler metal, if

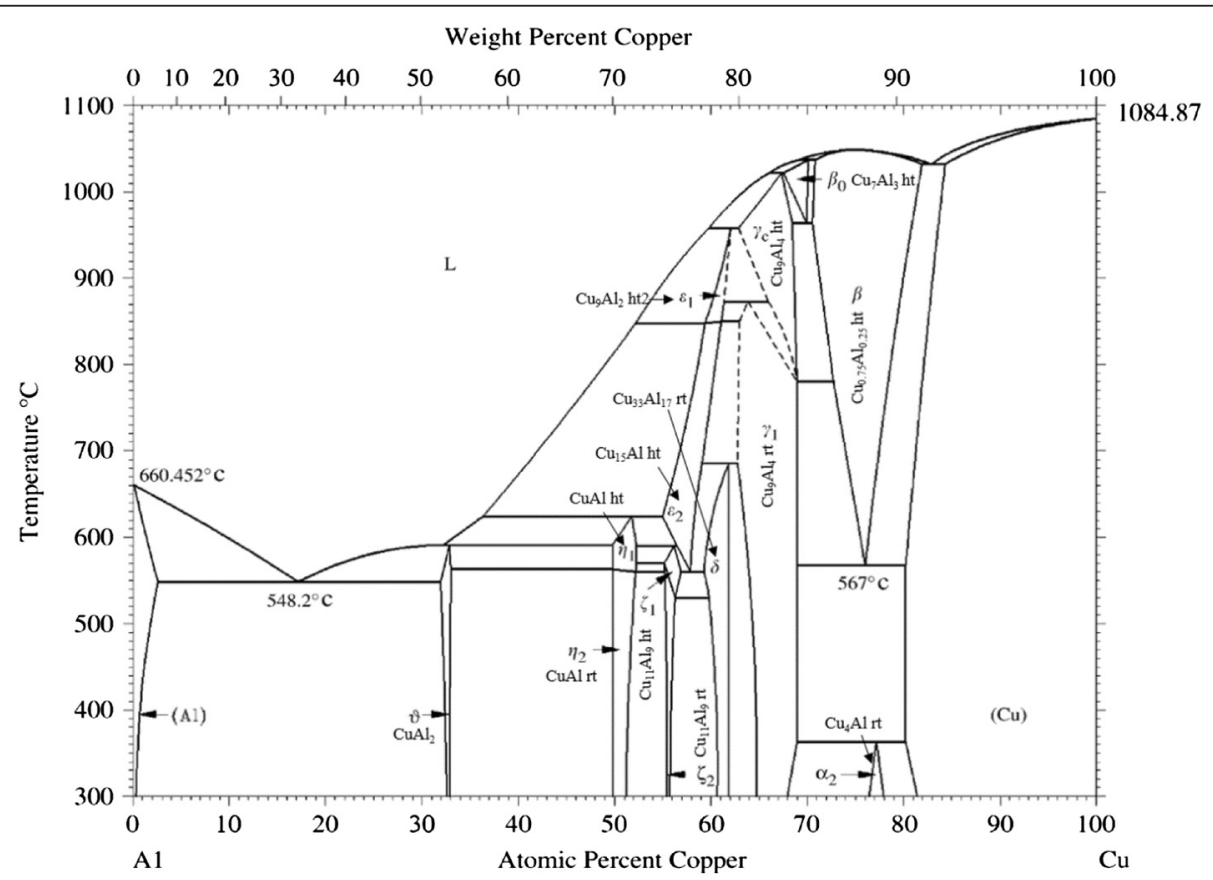

Fig. 1 Phase diagram of Al-Cu binary system (Xia, et al., 2008; Sujin, et al., 2014) 
used. For instance, voids were formed in an $\mathrm{Al}-\mathrm{Cu}$ brazed joint due to the Kirkendall effect and due to improper dilution between the $\mathrm{Al}$ and $\mathrm{Cu}$ atoms and the filler metal $\mathrm{Zn}$ atoms. This improper dilution occurred because the $\mathrm{Al}-\mathrm{Cu}$ binary system had higher affinity than the $\mathrm{Cu}-\mathrm{Zn}$ system so the $\mathrm{Cu}$ atoms tended to react with $\mathrm{Al}$ to form $\mathrm{CuAl}_{2}$ brittle intermetallic compounds (Lee, et al., 2002; Leonardo, et al., 2011; Feng \& Xue, 2013). The study by Balasundaram et al. (2014) showed that $\mathrm{Al}$ and $\mathrm{Cu}$ brazing with the addition of zinc as a filler metal produces macro-cracks at the edge of the $\mathrm{Cu}$ side. The macro-cracks formed because of the $\mathrm{Zn}$ dilution with $\mathrm{Al}$ and $\mathrm{Cu}$ pushing $\mathrm{Cu}$ aside, resulting in intergranular cracks by liquid metal embrittlement. So the ductile $\mathrm{Cu}$ phase during dilution transformed into brittle intermetallic structures when it made contact with the liquid metal (Nicholas \& Old, 1979). From the above studies, it can be noted that the welding filler metal with $\mathrm{Zn}$ has significant influence on the intermetallic compounds and defects formed during dilution of the base metals. Hence, appropriate selection of a filler metal corresponding to the base metals has to be considered when aiming for a reduction in defects in $\mathrm{Al}-\mathrm{Cu}$ joints.

The intermetallic compounds formed by the dilution effects and the composition gradients influence the solidification characteristics in the weld metal (Hayes, et al., 2011). The solidification of the intermetallic compounds influences the phase formation, which determines the joint properties (Sun \& Moisio, 1994). A brazed $\mathrm{Al}-\mathrm{Cu}$ joint with $\mathrm{Zn}-15 \mathrm{Al}$ filler metal had $\mathrm{CuAl}_{2}$ intermetallic compound formation during dilution, which increased the solidification time, thereby resulting in an improvement in properties (Feng et al. 2012b). Moreover, investigation of a laser welded $\mathrm{Al}-\mathrm{Cu}$ joint by Zuo, et al. (2014) showed variation in thickness in the intermediate layer due to solute gradients during dilution, and this solute gradient increased the solidification time, leading to property enhancement. Therefore, the type, amount and microstructural arrangement of the phases in the weld metal during the solidification of the intermetallic compounds and composition gradient influence the properties of the joint.
Besides the composition gradient and the dilution effect, the dilution and welding parameters also influence the weld properties of $\mathrm{Al}-\mathrm{Cu}$ joint through their effect on intermetallic compound formations. For instance, an experiment by Liu, et al. (2008) showed that a friction stir welded $\mathrm{Al}-\mathrm{Cu}$ joint had brittle intermetallic compound formation, prompting a degradation of properties. This weld properties degradation was due to incomplete dilution between the metals and the effect of the tool position in the welding process. On the other hand, $\mathrm{Li}$, et al. (2012) observed that the friction stir welded $\mathrm{Al}-\mathrm{Cu}$ joint in their work had complete dilution in the weld without intermetallic compound formation as shown in Fig. 2. This was achieved by offsetting the tool position. Moreover, the joint had good ductile properties. Thus, the welding parameters influencing the dilution reduce the formation of brittle intermetallic compounds in the weld metal.

From these studies, it is clear that the inappropriate selection of filler metal corresponding to base metals in the brazing process and improper welding tool position in the friction stir welding resulted in improper dilution between the base metals and filler metal. This in turn produced brittle intermetallic compounds, which results in degradation of properties and defect formation. However, the intermetallic compounds and composite gradients increase the solidification time during dilution in laser welding and brazing process. This leads to improvement in the weld mechanical properties.

\section{Influence of physical properties}

The significant difference between the physical properties of aluminium and copper results in brittle intermetallic structures and poses problems in weld metal formation for both fusion and solid-state welding processes. For instance, Sujin, et al. (2014) showed that in lap laser welding with $\mathrm{Cu}$ placed below $\mathrm{Al}$, the $\mathrm{Al}$ could not sink into the $\mathrm{Cu}$ substrate due to the higher density of $\mathrm{Cu}$. However, with $\mathrm{Cu}$ (top side) and $\mathrm{Al}$ (bottom side), the $\mathrm{Cu}$ could easily sink into the $\mathrm{Al}$ substrate resulting in proper dilution and a consequent improvement in
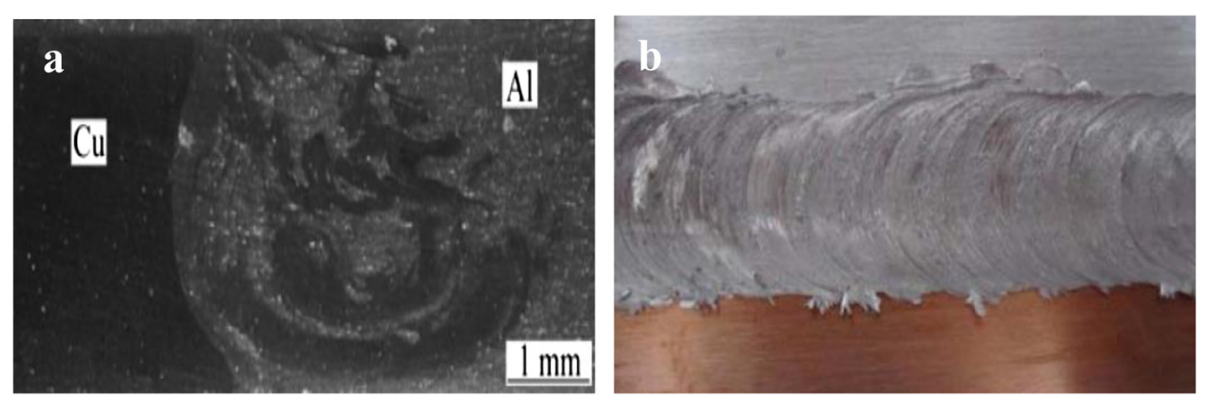

Fig. 2 (a) Macroscopic view of Al-Cu joints without intermetallic compounds and (b) surface appearance of the joint (Li, et al., 2012) 
properties. The physical properties play a vital role in the dilution of the metals. Some of the major physical properties of aluminium and copper are shown in Table 1, and their influence on weld metal formation is discussed below.

Melting temperature One of the most important factors in fusion welding of dissimilar joints as well as in solid-state welding processes is the melting temperature of the two base metals. A notable difference in the melting temperature of the base metals may result in rupture of the lower-melting-temperature metal (Hayes, et al., 2011). For instance, in a friction welded joint, $\mathrm{Al}$ melts more than $\mathrm{Cu}$, due to the lower melting temperature of $\mathrm{Al}$ compared to $\mathrm{Cu}$ (Sahin, 2009). Moreover, the study of Bisadi, et al. (2013) on the friction-stir welding process shows that joints with a significant difference in base metal melting temperatures welded with a high welding temperature have cavities in the transition zone of $\mathrm{Al}$ and $\mathrm{Cu}$. Previous study showed that residual thermal stresses and misfit strains are produced in $\mathrm{Al}-\mathrm{Cu}$ joints because of the significant difference in the melting temperatures of $\mathrm{Al}$ and $\mathrm{Cu}$ (Mai \& Spowage, 2004). Significant difference in melting temperature also affects the surface appearance of the joint. Lap laser welding with $\mathrm{Al}$ (topside) and $\mathrm{Cu}$ resulted in problems such as large weld bead formation and a large heat-affected zone on the $\mathrm{Al}$ side, due to the low melting temperature and the high absorptivity of the laser wavelength by $\mathrm{Al}$ (Weigl, et al., 2011; Sujin, et al., 2014). The above studies show that the difference in melting temperature has effects on defects and the surface appearance of $\mathrm{Al}-\mathrm{Cu}$ joints and thus influences weld mechanical properties.

Some studies show that the melting temperature difference leads to the formation of brittle and highly electrical-resistant intermetallic compounds in the weld metal (Song-bai, et al., 2003; Ouyang, et al., 2006; Sahin, 2009). The degradation in weld properties can be avoided by considering the difference in melting temperature during the joint design stage and by the use of suitable filler metal and welding parameters.

Thermal conductivity Significant difference in the thermal conductivity of the metals in a dissimilar

Table 1 Physical properties of aluminium and copper

\begin{tabular}{lll}
\hline Property & Copper & Aluminium \\
\hline Density & $8.9 \mathrm{~g} / \mathrm{cm}^{3}$ & $2.71 \mathrm{~g} / \mathrm{cm}^{3}$ \\
Melting temperature & $1083^{\circ} \mathrm{C}$ & $660{ }^{\circ} \mathrm{C}$ \\
Thermal conductivity & $390 \mathrm{~W} / \mathrm{mK}$ & $226 \mathrm{~W} / \mathrm{mK}$ \\
Co-efficient of thermal expansion & $17 /{ }^{\circ} \mathrm{C} .10^{6}$ & $24 /{ }^{\circ} \mathrm{C} .10^{6}$ \\
Specific heat capacity & $385 \mathrm{~kg}{ }^{\circ} \mathrm{C}$ & $946 \mathrm{~kg}{ }^{\circ} \mathrm{C}$ \\
\hline
\end{tabular}

joint results in more heat being conducted to the metal with higher thermal conductivity, leading to uneven distribution of heat and localised melting of the metal (Hayes, et al., 2011). This uneven distribution of heat and localised melting degrades the weld properties. For instance, high hardness values were found in the $\mathrm{Cu}$ region of a friction welded $\mathrm{Al}-\mathrm{Cu}$ joint, due to the higher thermal conductivity of $\mathrm{Cu}$ than Al (Sahin, 2009). Such hardness can result in brittleness at the $\mathrm{Cu}$ region, which can lead to easy fracture of the joint. Moreover, Takehiko, et al. (1999 (Online-2010)) noticed in their study of an ultrasonic welding process that decrease in the bond strength between $\mathrm{Al}$ and $\mathrm{Cu}$ due to the high thermal conductivity of $\mathrm{Cu}$. The above studies show that solid-state welding processes face problems resulting from the significant difference in thermal conductivity of the base metal. Fusion welding processes face additional problems caused by filler metal addition to the joint.

$\mathrm{Al}$ and $\mathrm{Cu}$ have high thermal diffusivity, which leads to difficulties in joining by fusion welding processes (Sahin, 2009). For instance, Hailat, et al. (2012) found that lap laser welding of $\mathrm{Al}-\mathrm{Cu}$ joints with a tin foil alloy as filler metal gave shallower penetration in the $\mathrm{Cu}$ side and greater porosity formation in the weld compared to a weld formed without filler metal. The filler metal absorbed the laser energy because of its high thermal conductivity and the high reflectivity of the base metals, which resulted in a barrier layer for thermal conduction between the base metals (Hailat, et al., 2012). Sujin, et al. (2014) reported only partial penetration in the weld metal with laser welding.

To mitigate the problems caused by thermal conductivity, the heating sources in fusion welding processes can be directed to the metal with higher thermal conductivity (i.e. $\mathrm{Cu}$ in an $\mathrm{Al}-\mathrm{Cu}$ joint) or the metal with higher thermal conductivity can be pre-heated (Hayes, et al., 2011).

In some cases, however, a notable difference in thermal conductivity has a beneficial effect on the joint: for example, no heat-affected zones were produced in a study using friction stir welding, due to the high sink rate resulting from the high thermal conductivity of $\mathrm{Cu}$ (Sarvghad-Moghaddam, et al., 2014).

The above studies show that the notable difference in the thermal conducting property of the metals has both beneficial and detrimental effects on the joint properties. However, the difference in the thermal conducting property has no effect on the intermetallic compound formation. The detrimental effects can be reduced by taking into account the metal properties when designing the joint or by introducing an appropriate third metal (i.e. filler metal) into the 
joint. Therefore, the selection of filler metal requires consideration of the base metals and its thermal conductivity for generating high joint properties (Hayes, et al., 2011).

Co-efficient of thermal expansion The thermal expansion co-efficient is considered an important factor due to its effect on the formation of discontinuities in the joint, which significantly reduce the weld properties. For instance, a friction stir welded $\mathrm{Al}-\mathrm{Cu}$ joint (Bisadi, et al., 2013) had cavity formation in the weld metal because of the significant difference in thermal expansion, as shown in Fig. 3. The aluminium particles were forced into the copper side, resulting in a macro-structural cavity in the weld metal after the quenching process.

With fusion welded $\mathrm{Al}-\mathrm{Cu}$ joints, the significant difference in thermal expansion can result in hot cracks during welding and cold cracks when the joint is in service. The cracking occurs due to the tensile stresses in one metal and the compressive stresses in the other that are induced during solidification of the metals (Hayes, et al., 2011). This phenomenon was also noted in a study by Weigl, et al. (2011) on laser welding with adaptive filler materials (i.e. AlSi12 and $\mathrm{CuSi3}$ ), which found crack initiation in the joint as a result of the high tensile stresses caused by the notable difference in thermal expansion.

Studies show that joint with the difference in thermal expansion between the metal has effects on surface appearance and weld geometry (Hayes, et al., 2011). For instance, the study of Zuo, et al. (2014) on the laser welding of Al-Cu joints reported the formation of upward convexity in the transition layer due to the higher coefficient of expansion of $\mathrm{Al}$ than $\mathrm{Cu}$, as shown in Fig. 4. This upward convexity in the transition layer resulted in insufficient dilution between the metals and a shallow and broad weld seam.

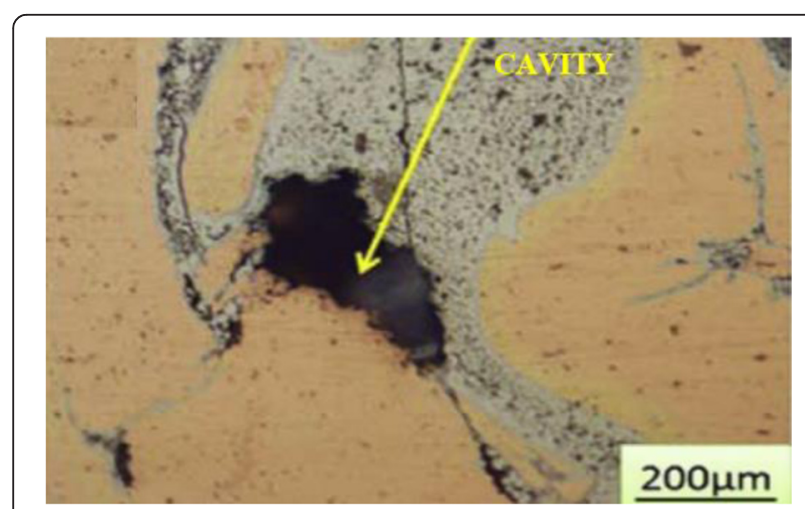

Fig. 3 Cavity formation in the transition layer in a friction stir welded joint (Bisadi, et al., 2013)

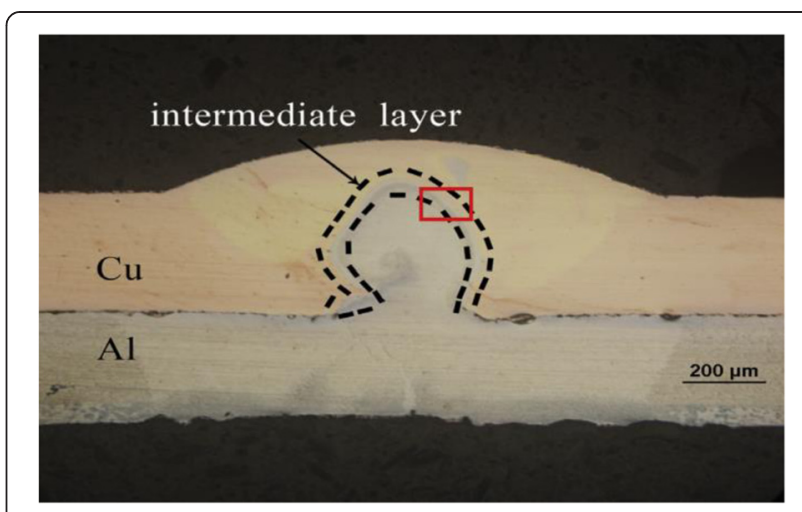

Fig. 4 Concavity formation in the transition layer of an Al-Cu laser welded joint (Zuo, et al., 2014)

The abovementioned studies show that the significant difference in thermal expansion can lead to defect formation and rupture of the joint in both fusion welding and solid-state welding processes. However, the difference has no effect on the formation of intermetallic compounds. Post weld heat treatment can mitigate defects formation caused by the thermal expansion differences.

\section{Influence of welding parameters}

Welding parameters vary depending on the welding processes and techniques adopted and the $\mathrm{Al}$ and $\mathrm{Cu}$ alloy used. The chosen parameters determine metal dilution, properties formation, and the surface appearance of the joint, and the properties of the base metals and filler metal, if used, must be considered in welding parameter selection. However, various studies concur that in dissimilar joints, solid-state welding shows better joint formation than fusion welding processes. For instance, the mechanical properties of $\mathrm{Al}-\mathrm{Cu}$ joints can be enhanced in friction welding processes by selecting appropriate friction time, pressure and upset pressure. Sahin (2009) showed that the tensile strength of a joint increases until a peak value and then decreases gradually with further increase in friction pressure and time. This decrease in strength is due to heat dissipation and the formation of brittle intermetallic compounds as a form of grey layer at the interface region of the joint.

The joint design has effects on the welding parameters, which in turn influence the weld properties. This was demonstrated in an $\mathrm{Al}-\mathrm{Cu}$ brazed joint, in which large spacing for the weld seam improved the electrical performance of the Al-Cu joint (Solchenbach et al. 2014). With lap laser welding, Sujin, et al. (2014) showed that the joint has complete penetration when the $\mathrm{Al}$ is placed above the $\mathrm{Cu}$, whereas the opposite placing gave only partial penetration into the Al. The partial penetration was due to the high welding speed used in the study and the high reflectivity and thermal conductivity of $\mathrm{Cu}$. It was further noted that 
increasing the laser welding speed reduced the amount of intermetallic compounds formed and improved the tensile property of the joint. Mai and Spowage (2004), on the other hand, found solidification cracks in a laser welded joint as a result of high welding speed. Moreover, high welding speed reduces the shear strength of the joint (Zuo, et al., 2014). Research has also suggested that a uniform and successful weld between $\mathrm{Al}$ and $\mathrm{Cu}$ requires high pulse power for short duration (Mai \& Spowage, 2004; Zuo, et al., 2014). The above section shows that the combined effects of welding parameters and other factors (i.e. joint design and physical properties of the base metal) influence $\mathrm{Al}-\mathrm{Cu}$ joints by reducing the weld properties and by forming the brittle intermetallic compounds.

However, in some cases, studies have shown that the weld properties have been influenced only by the welding parameters. The corrosion resistance in joints formed by friction stir welding has been improved by welding parameter adjustments (Jariyaboon, et al., 2007; Krishnan, et al., 2009). Akinlabi, et al. (2014) analysed the corrosion properties of friction stir welded joints and found that the joint corrosion rate decreased as the rotation speed of friction stir increased. Moreover, the rotation speed improved the better material flow in the joint through stirring action of the tool (Liu, et al., 2008). Changes in friction stir welding tools with the same welding parameters have resulted in variation in the weld microstructure and properties. Different tool configurations vary the frictional heating effects thereby influencing the mode of deformation in metal (Mubiayi and Akinlabi, 2013). For instance, SarvghadMoghaddam, et al. (2014) showed the dominant impact of the tool on the properties and microstructure in the weld by varying the tool shoulder and pin. Galvão et al. (2010; 2012) who experimented on friction stir welding using scrolled and conical friction stir tools showed that the tool has immense influence on the production of successful welded joints. With a conical shoulder tool, $\mathrm{Al}$ at the advancing side resulted in irregular microstructure; however, defect formation was reduced. $\mathrm{Al}$ at the retreating side resulted in intermetallic compound formation from the mechanical mixing of $\mathrm{Al}$ into the $\mathrm{Cu}$ matrix. Welds formed by a conical tool had smooth appearance and grain refinement. With a scrolled shoulder tool, both joints had brittle intermetallic compound formation through the downward material flow. Weld surface had a shiny weld bead with deep voids. Most research suggests that to reduce the intermetallic compounds in friction stir welding, the tool should be placed in the $\mathrm{Cu}$ at the retreating side (Liu, et al., 2008; Tan, et al., 2013). However, Xue, et al.(2010) suggest that offsetting the tool in the $\mathrm{Al}$ side reduces the intermetallic compound thickness and defect formation and improves bending and tensile properties. Their study also showed that a thin and uniform continuous layer of intermetallic compound improved the bonding strength and mechanical properties of the joint. Appropriate selection of tools and tool positioning on material (i.e. advancing side and retreating side) in the friction-stir welding process reduces the intermetallic compound formation and thereby improves the joint strength.

However, the variation in welding speed and heat input can have a detrimental effect on the joint by leading to discontinuities. When studying $\mathrm{Al}-\mathrm{Cu}$ joints formed by friction stir welding, Tohid, et al. (2010) showed that a high welding speed results in cavity formation. The effects of a low welding speed were different; micro-cracks formed adjacent to the $\mathrm{Cu}$ particles along the joint, as shown in Fig. 5. Yong, et al. (2006) stated that cavity formation is due to inadequate heat input to dilute the metals. Yong et al. also noted that heat generation by the tool that plunged along the joint was inversely proportional to the welding speed. As in the study by Tohid, et al (2010), Bisadi, et al. (2013) also found cavity formation at high welding temperature. At low welding temperature, in contrast to Tohid et al.'s result, the joint was found to have channel defects. The reason for these defect formations was high copper diffusion to the $\mathrm{Al}$ sheet.

The welding parameters clearly influence the joint through the formation of intermetallic compounds and their effect on weld properties and defects. The major parameters influencing the $\mathrm{Al}-\mathrm{Cu}$ weld properties are welding speed, heat input and tool position. Optimal parameters vary according to the requirements for service.

\section{Influence of filler metal}

Filler metal addition generally plays a vital role in welding of dissimilar joints. The selection of an appropriate filler metal depends the physical properties of the base metals and the welding process used. Moreover, the joint design requirements should be compatible with the selected filler metal. Criteria have been presented for selection of filler metals for dissimilar joints to ensure better weld metal properties and successful joint without any discontinuities (Hayes, et al., 2011). When selecting an appropriate filler metal for a joint, the filler metal spreadability should be considered. The spreadability of filler metal on the substrate is dependent on one of two factors: mutual dilution between the metals or the formation of intermetallic compounds (Feng et al. 2012b). For instance, a Zn-Al filler metal used in a brazing process has a linear increase in wettability (i.e. spreadability) on the $\mathrm{Al}$ and $\mathrm{Cu}$ substrate with increasing $\mathrm{Al}$ content in the filler metal as shown in Fig. 6 (Feng et al. 2012b). However, the mutual dilution rate of the filler metal on the $\mathrm{Al}$ substrate is reduced, which results in the formation of intermetallic compounds. Additionally, microhardness in the brazing seam increases with increased 

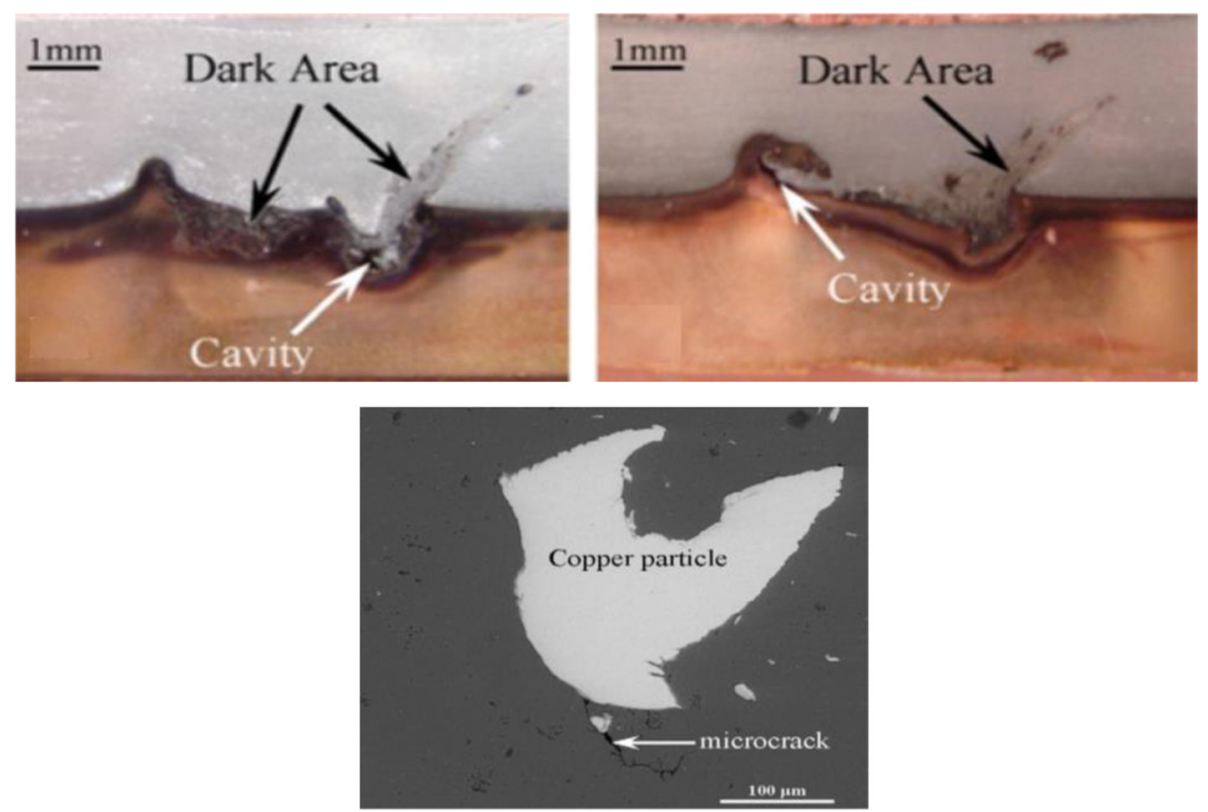

Fig. 5 Cavity and micro-cracks formation produced by friction stir welding in the weld metal (Tohid, et al., 2010)

$\mathrm{Al}$ content in the $\mathrm{Zn}$-Al filler metal resulting in brittle fracture of the joint.

Studies show that addition of appropriate elements (i.e. based on the properties of the base metal) to the filler metal have improved $\mathrm{Al}-\mathrm{Cu}$ weld properties and reduced intermetallic compounds. A study by Feng, et al. (2013) on brazing Al-Cu joints with the addition of $\mathrm{Ti}$ to $\mathrm{Zn}-22$ Al filler metal showed that the filler metal wettability decreased with increase in Ti content, as shown in Fig. 7. However, the increase in $\mathrm{Ti}$ content led to a reduction of intermetallic compounds in the joint and an increase in joint

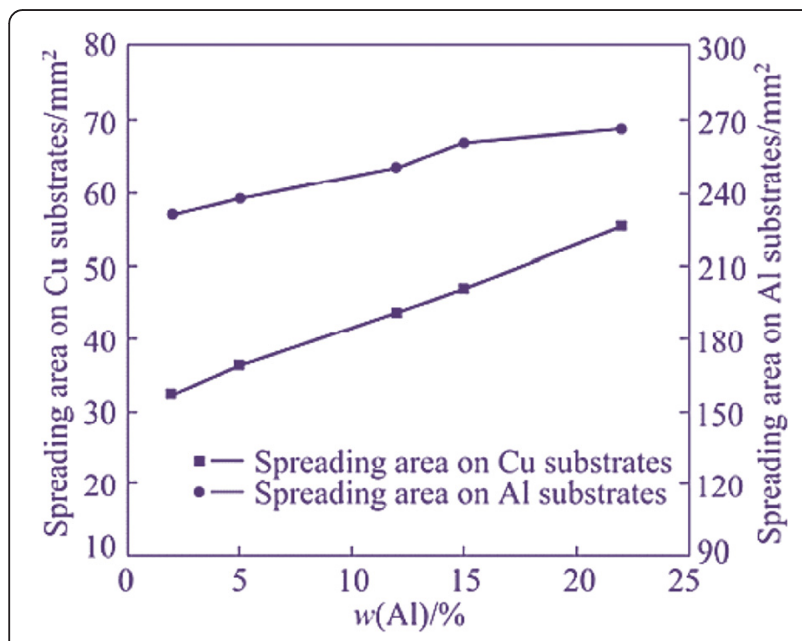

Fig. 6 Spreading areas on Al and Cu substrates with increasing Al content in Zn-Al filler metals (Feng et al. 2012b) shear strength. The addition of Ce to the filler metal instead of Ti, studied by Feng and Xue (2013), resulted in a thinner intermetallic layer. The layer formed by a $\mathrm{Zn}-22 \mathrm{Al}-0.05 \mathrm{Ce}$ filler metal was thinner than that with a $\mathrm{Zn}-22 \mathrm{Al}$ filler metal because the Ce changed the atom diffusion and suppressed the intermetallic compound layer growth, which resulted in an improvement in weld properties.

Studies show that the intermetallic compounds formed by filler metal addition can have beneficial effects on weld properties. For instance, Xia, et al. (2008) showed that a weld formed by an Al-Si filler metal had a

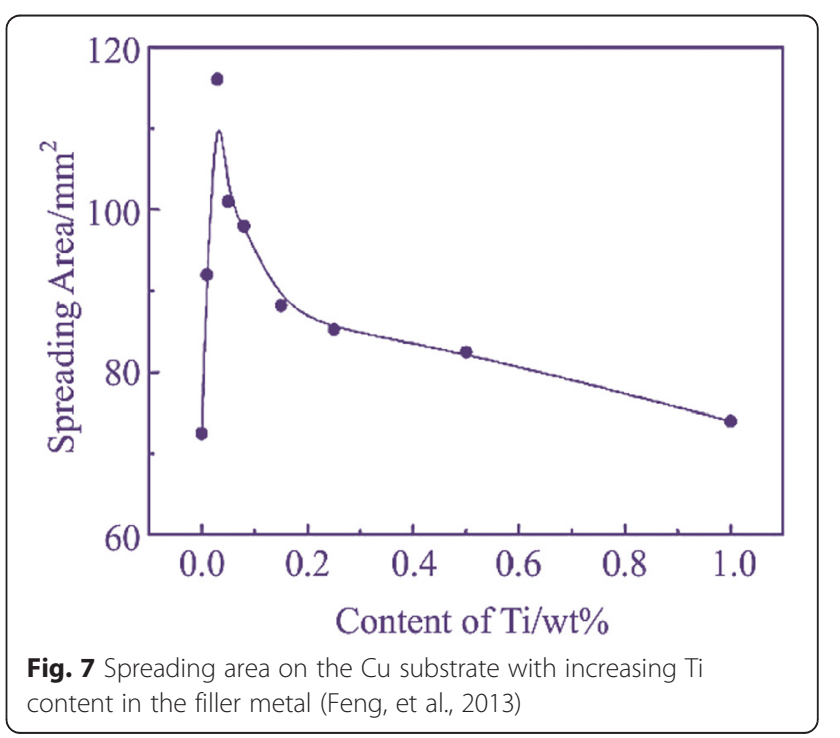


prismatic bulky intermetallic structure on the side of the $\mathrm{Al}$. The growth in the prismatic $\mathrm{Al}$ grain was due to the eutectic reaction of the $\mathrm{Al}$ base metal and $\mathrm{Si}$ in the filler metal. The uniform growth of the $\mathrm{Al}$ prismatic structure had a beneficial effect on the mechanical properties of the weld metal.

As well as reduction in intermetallic compounds, filler metal addition can improve other properties and reduce defects. Research has shown that appropriate filler metals such as $\mathrm{Zn}$ - $\mathrm{Al}$ alloys for a brazed $\mathrm{Al}-\mathrm{Cu}$ joint give high corrosion resistance and better mechanical properties compared to other filler metals (Berlanga-Labari et al. 2011; Feng et al. 2012b; Yan, et al., 2013). Research has also shown that the addition of a suitable filler metal having a low melting temperature results in a reduction of the residual stress in $\mathrm{Al}-\mathrm{Cu}$ joints (Xiao et al. 2013). An inappropriate filler metal, on the other hand, results in defect formation in the weld metal. This was demonstrated in the studies by Berlanga-Labari, et al. (2011), in which it was seen that brazing of an $\mathrm{Al}-\mathrm{Cu}$ joint with a $\mathrm{Zn}$-Al eutectic filler metal resulted in a uniform microstructure but with defects such as porosity and cracks. In the case of laser welding, Weigl, et al. (2011) conducted an experiment on adapted filler materials that were used in thermal welding and a brazing process (AlSi12 and $\mathrm{CuSi3}$ ). The weld metal showed microcracks in the AlSi12 filler material; welds formed by $\mathrm{CuSi} 3$ had macro-crack formation and low dilution but were better than welds formed without filler metals. In conclusion, the use of appropriate filler metal in $\mathrm{Al}-\mathrm{Cu}$ joints improves the properties of the joint, by assisting in proper dilution, which reduces the intermetallic compounds and leads to fewer defects.

\section{Influence of heat treatment}

In some cases, heat treatment can be beneficial to one of the base metals but unfavourable to the other base metal, which will result in weld defect formation. In the experimental study of solid-state welding, Wonbae, et al. (2005) showed that a friction welded joint had different intermetallic compounds after long annealing time and the thickness growth of the intermetallic compounds in the weld was increased by high annealing temperatures, which is shown in Fig. 8. Thus, long annealing time and high annealing temperature resulted in a degradation of properties.

The same phenomenon was also found in experiments on Al-Cu brazed joints by Feng and Xue (2013). Their work showed that the intermetallic layer grew with increase in ageing time. In addition, the shear strength decreased with increased ageing time, due to growth in the intermetallic compound thickness. It was noted that $\mathrm{Al}-\mathrm{Cu}$ brazed joints formed with a Zn-22Al-0.05Ce filler metal had higher shear strength compared to those formed with a $\mathrm{Zn}-22 \mathrm{Al}$ filler metal. With a nominal ageing time, the joint had a ductile fracture mode; however, increased ageing time changed the joint to brittle fracture mode.

The above studies indicate that increasing the heat treatment temperature and time above the nominal level results in thickness growth of intermetallic compound by greater dilution between the metals thereby, ultimately leading to defects formations and reduction in the properties of the joint.

\section{Factors affecting Al-Cu joint properties while in service}

Major joint problems usually occur only when the joint is subjected to service conditions. $\mathrm{Al}-\mathrm{Cu}$ joints are mostly used in electrical industries as electrical connectors, so a key consideration is oxidation, since $\mathrm{Al}-\mathrm{Cu}$ joints are easily oxidised, resulting in resistance to electrical flow (Klauke, 2012). Therefore, joint properties and microstructure formation when the joints are in service need to be considered.

\section{Physical and mechanical properties of the joint}

The properties of the weld metal formed depend on the weld metal composition and intermetallic phases formed (Hayes, et al., 2011). For instance, Wonbae, et al. (2005) showed that friction stir welded joint have low conductive intermetallic compound formation, which results in increased electrical resistance in the joint. Braunović and Alexandrov 1994 showed friction welded $\mathrm{Al}-\mathrm{Cu}$ joints submitted to electrical current exhibited substantial cracking along the joint as well as in the phases formed in the joint. Joints operating at high temperature and high current displayed growth of intermetallic compounds and increased electrical resistance in the joint. The cracking and increased electrical resistance were due to the diffusion of $\mathrm{Cu}$ atoms in the interface region and intermetallic compound formation. Solchenbach, et al. (2014) showed a relation between the electrical resistance and the shear strength in $\mathrm{Al}-\mathrm{Cu}$ laser brazed joints. As shear strength increased, the electrical resistance in the joint decreased over time, as shown in Fig. 9.

The above studies show that the electrical properties are affected by the intermetallic compounds formed in the joint while it is in service. The studies also show that the intermetallic compounds affect mechanical properties of the joint. For instance, the study of Braunović and Alexandrov 1994 showed that high microhardness in the intermetallic compounds resulted in brittleness leading to easy fracture and low mechanical strength of the joint. A similar finding has been reported for brazing of an aluminium and copper joint containing an $\mathrm{Al}_{2} \mathrm{Cu}$ phase (Feng et al. 2012b). The hardness characteristics created by the $\mathrm{Al}_{2} \mathrm{Cu}$ intermetallic compounds result in increased brittleness in the weld metal, which can act as a stress raiser leading to the initiation of cracks. A joint 

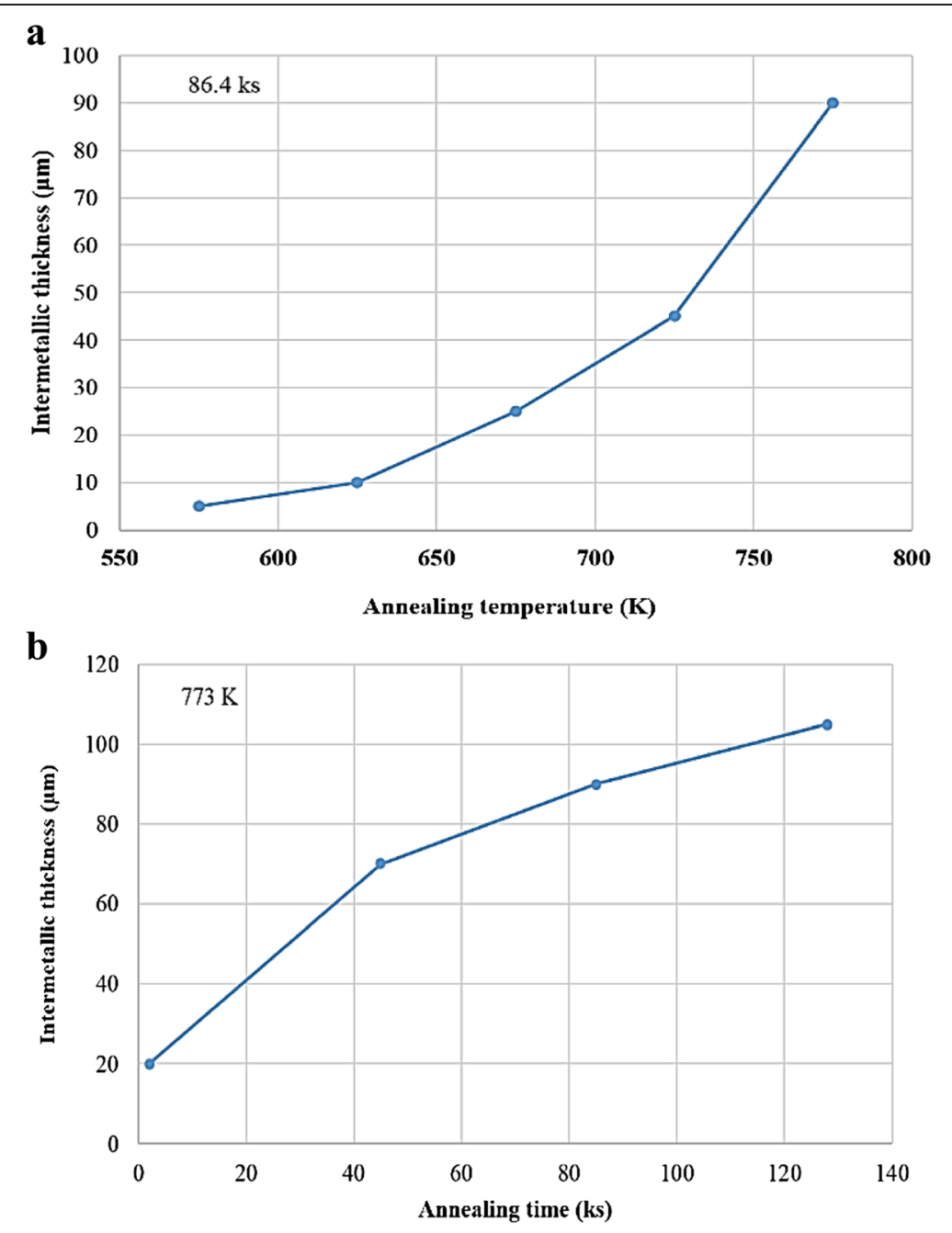

Fig. 8 Intermetallic thickness variation by (a) varying annnealing temperature and (b) varying annealing time (Wonbae, et al., 2005)

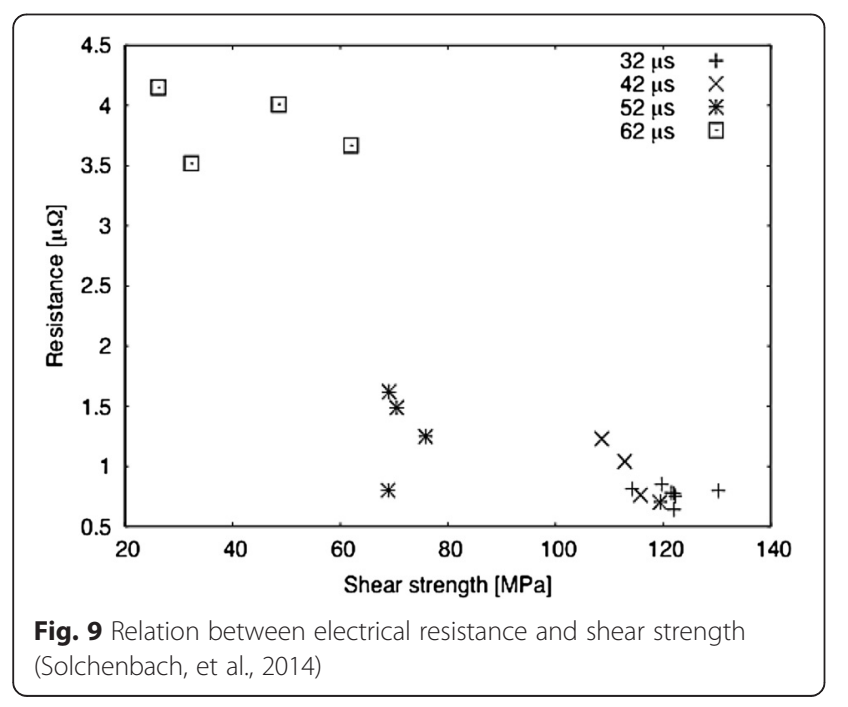

formed by Zn-15Al filler metal had the highest shear strength because of the uniform distribution of the $\mathrm{Al}_{2} \mathrm{Cu}$ intermetallic compound, which could also reduce the electrical resistance (Feng et al. 2012b).

With laser welding, Sujin, et al. (2014) showed that laser-welded $\mathrm{Cu}-\mathrm{Al}$ joints fracture easily due to the large weld zone and the formation of intermetallic compounds $\left(\mathrm{CuAl}\right.$ and $\left.\mathrm{Al}_{2} \mathrm{Cu}\right)$. The work of Weigl, et al. (2011) on laser welding with adapted filler materials (i.e. AlSi12 and $\mathrm{CuSi} 3$ ) showed that the hardness value decreased more with the AlSi12 filler metal, due to uniform distribution of the $\mathrm{Cu}$ concentration and intermetallic compounds. Additionally, the weld formed with the AlSi12 filler metal had the highest ductile strength, followed by the weld made with the CuSi3 filler metal, with the weld formed without filler metals having the lowest ductile strength. The ductility in the weld that was made using an AlSi12 filler metal was due to a less coarse honeycomb structure. 
From the discussion in this section, it can be observed that weld properties influences the stability during in-service condition through intermetallic compound formation. Moreover, low weld properties and brittle intermetallic compound phase formation in the joint can result in failure of the joint while in service.

\section{Stability of microstructure in the joint}

Dissimilar joints vary in the concentration of atoms and their activity (i.e. potential chemical gradient) in the weld metal. This activity can lead to the diffusion of atoms with or against the gradient concentration of the metal. Therefore, it is difficult to predict the properties or specific atom migration in a dissimilar joint during the welding processes as well as in service at high temperatures. The migration of a specific atom or atom movement depends on the temperature, as well as the time, and results in changes in the properties and stability of the weld metal (Joseph 2006; Hayes, et al., 2011). Numerous studies on $\mathrm{Al}-\mathrm{Cu}$ joints have shown that the type and microstructure of the interface formed in the joint determine the stability of the joint. In addition, appropriate thickness and fine distribution of the intermetallic layer have a positive effect on the properties of the joint (Pang, et al., 2001; Song, et al., 2003; Huseyin et al. 2005; Lin, et al., 2009). For instance, Lawrence, et al. (1998) noticed that a $\mathrm{Cu}-\mathrm{Al}$ joint welded by friction stir welding had a complex intercalation with swirl and vortex features that was unstable at the interface. Zhao, et al. (2013) noted the same swirling deformation in ultrasonic spot-welded $\mathrm{Al}-\mathrm{Cu}$ joints as shown in Fig. 10a. Their study suggested that the swirl development was due to high energy as the tool tip penetrated more into the metal, leading to coarse displacement. If a joint is placed in a high-temperature environment, swirl deformation can also result from displacement, making the joint unstable. The swirl has the beneficial effect of increasing shear strength but the detrimental effect of creating void formation in the weld metal, as shown in Fig. 10b. (Zhao, et al., 2013). To avoid failure of the joint while in service, these intercalation and microstructural phase formations should be considered at the design stages and addressed with appropriate welding parameters.

Feng et al. (2012b) found for Al-Cu brazed joints that the intermetallic compounds formed on the $\mathrm{Cu}$ substrate changed phase as a result of variation of the $\mathrm{Al}$ content in the filler metal ( $\mathrm{Zn}-\mathrm{Al})$. In addition, increased $\mathrm{Al}$ content in the filler metal led to bulk intermetallic formation, which increased the melting temperature and had a detrimental effect on the properties of the joint. Feng, et al. (2013) found that adding $\mathrm{Ti}$ to the $\mathrm{Zn}$-Al filler metal stabilised the microstructural changes in the interface region by transforming the bulk structure into a needle shape structure. The stability of the microstructure influences the $\mathrm{Al}-\mathrm{Cu}$ joint properties through the composition gradient formed and intermetallic structure formation resulting in microstructural change.

\section{Resistance to corrosion and oxidation characteristic}

In dissimilar weld metal, corrosion can occur in either the joint phase or anodic metal due to the formation of galvanic cells. Galvanic cell formation is a result of a localised cell between the joint phases and leads to severe defects in the weld metal, such as hydrogen embrittlement and stress corrosion. For instance, the study by Acarer (2012) on explosive welding showed galvanic corrosion on $\mathrm{Al}-\mathrm{Cu}$ bimetal, as the $\mathrm{Al}$ acted as an anode due to the high electronegativity. Consequently, $\mathrm{Al}$ in the intermetallic zone was subject to more corrosion than the $\mathrm{Cu}$ side, which can be seen from Fig. 11.

Study of bimetallic corrosion in seawater indicated that $\mathrm{Al}$ was unprotected from severe corrosion due to the activity and passivity properties of $\mathrm{Al}$ and $\mathrm{Cu}$ (Francis 2000). Other studies on corrosion have shown that $\mathrm{Al}-\mathrm{Cu}$ weld metal corrodes due to moisture trapped during welding and can fail while in service. This corrosion occurs more in $\mathrm{Al}$, which is the less noble metal (anode) than in $\mathrm{Cu}$ (Solacity, 2011).

Corrosion is also promoted by the pitting action and the ionisation tendency between the copper and aluminium, which consequently results in a smaller

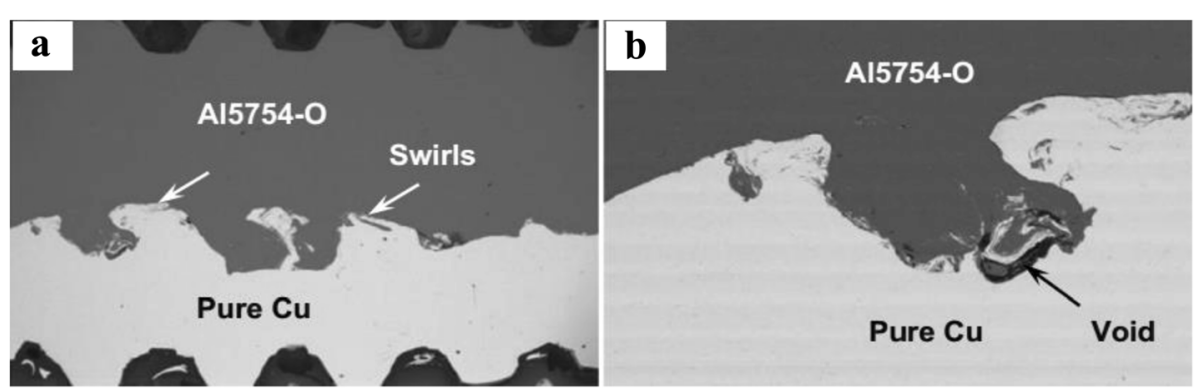

Fig. 10 a Formation of swirls and b void formation in an Al-Cu joint (Zhao, et al., 2013) 

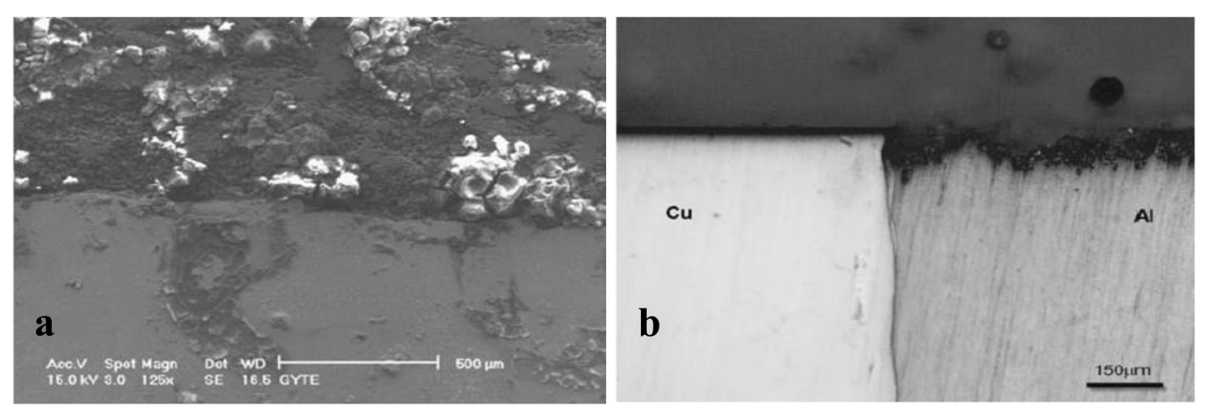

Fig. 11 a Corroded bimetal of an Al-Cu joint and $\mathbf{b}$ cross-sectional view of corroded Al-Cu bimetal (Acarer, 2012)

contact surface area. The small contact area between the metals leads to loosened connection between the two metals and produces noise during the arcing (Solacity, 2011). In a friction-stir welded joint, galvanic corrosion occurs at the interface region of the weld due to the high-temperature gradient, which results in degradation of the joint properties. In addition, high-temperature corrosion can occur due to significant difference in the chemical composition of the weld metal. When the dissimilar weld metal operates at high temperatures, oxidation occurs due to the variation in the composition of the weld metals. This oxidation leads to notches in the weld metal, which act as stress raisers (Joseph 2006).

To avoid corrosion in the joints, corrosion behaviour should be considered when selecting the materials for a dissimilar joint. When a third metal (filler metal) is used, dilution of the metal and third metal corrosion behaviour should also be considered. Shielding gas or transition compound particles can be used for moisture prevention (Solacity, 2011). It can be noted from the studies that

Table 2 Comparison between friction stir welding, laser welding and brazing in welding of Al (1060) and pure Cu

\begin{tabular}{|c|c|c|c|c|}
\hline Welding process & & IMC phase formed & Advantages and disadvantages & Defects \\
\hline \multirow[t]{7}{*}{ Laser beam welding } & \multirow{4}{*}{$\begin{array}{l}\text { Lap welding of } \mathrm{Al}(1060) \text { to } \\
\text { pure Cu by ND:YAG laser } \\
\text { (Zuo, et al., 2014) }\end{array}$} & $\mathrm{Y}_{2}-\mathrm{Cu}_{9} \mathrm{Al}_{4}$ & \multirow{3}{*}{$\begin{array}{l}\text { - } \mathrm{\gamma}_{2}-\mathrm{Cu}_{9} \mathrm{Al}_{4} \text { had positive influence on the } \\
\text { mechanical properties of joint }\end{array}$} & \multirow[t]{4}{*}{ - Upward convexity } \\
\hline & & $\mathrm{a}-\mathrm{Al}+\theta-\mathrm{CuAl} \mathrm{I}_{2}$ & & \\
\hline & & $(a+\theta)$ eutectic & & \\
\hline & & $\mathrm{a}-\mathrm{Al}$ & $\begin{array}{l}\text { - Due to the brittle phase } \theta-\mathrm{CuAl}_{2} \text {, the joint } \\
\text { fails by fracture }\end{array}$ & \\
\hline & \multirow{3}{*}{$\begin{array}{l}\text { Lap welding of } \mathrm{Al}(1050) \text { to } \\
\text { pure Cu by FIBRE laser } \\
\text { (Sujin, et al., 2014) }\end{array}$} & $\mathrm{Cu}_{9} \mathrm{Al}_{4}$ & \multirow{3}{*}{$\begin{array}{l}\text { - Due to the brittle phase of } \mathrm{CuAl}_{2} \text { and } \\
\text { CuAl, the joint fails by fracture }\end{array}$} & \multirow{3}{*}{$\begin{array}{l}\text { - Low welding speed leads } \\
\text { to crack formation }\end{array}$} \\
\hline & & $\mathrm{CuAl}_{2}$ & & \\
\hline & & CuAl & & \\
\hline \multirow[t]{6}{*}{ Friction stir welding } & \multirow{3}{*}{$\begin{array}{l}\text { Lap welding of } \mathrm{Al}(1060) \\
\text { to pure Cu with offset in } \\
\text { Al side (Abdollah-zadeh, } \\
\text { et al., 2008) }\end{array}$} & $\mathrm{Cu}_{9} \mathrm{Al}_{4}$ & \multirow{3}{*}{$\begin{array}{l}\text { - AlCu has increased hardness property and } \\
\text { strengthened the joint. }\end{array}$} & \multirow[t]{3}{*}{ - No defects were found. } \\
\hline & & $\mathrm{CuAl}_{2}$ & & \\
\hline & & CuAl & & \\
\hline & \multirow{3}{*}{$\begin{array}{l}\text { Lap welding of } \mathrm{Al}(1060) \text { to } \\
\text { pure Cu (Tohid, et al., 2010) }\end{array}$} & $\mathrm{Cu}_{9} \mathrm{Al}_{4}$ & \multirow{3}{*}{$\begin{array}{l}\text { - } \mathrm{CuAl}_{2} \text { and } \mathrm{Cu}_{9} \mathrm{Al}_{4} \text { were formed in the dark } \\
\text { area, which was also the reason for defect } \\
\text { formations }\end{array}$} & \multirow{2}{*}{$\begin{array}{l}\text { - Cavity formation due to } \\
\text { higher welding speed }\end{array}$} \\
\hline & & $\mathrm{CuAl}_{2}$ & & \\
\hline & & & & $\begin{array}{l}\text { - Formation of micro-cracks } \\
\text { duetolowwelding speeds }\end{array}$ \\
\hline \multirow[t]{3}{*}{ Brazing } & $\begin{array}{l}\text { Lap welding of } \mathrm{Al}(1060) \text { to } \\
\text { pure Cu with various alloys } \\
\text { in Zn-Al filler metal } \\
\text { (Feng et al. 2012b) }\end{array}$ & $\mathrm{CuAl}_{2}$ & $\begin{array}{l}\text { - } \mathrm{CuAl}_{2} \text { improved the mechanical } \\
\text { properties, such as microhardness and } \\
\text { shear strength }\end{array}$ & $\begin{array}{l}\text { - Cracks can initiate or } \\
\text { propagate if the } \\
\text { intermetallic compound } \\
\text { is not diluted. }\end{array}$ \\
\hline & \multirow{2}{*}{$\begin{array}{l}\text { Lap welding of } \mathrm{Al}(1060) \text { to } \\
\text { pure Cu with addition of } \\
\text { Ti in Zn-22Al filler metal } \\
\text { (Feng, et al., 2013) }\end{array}$} & CuZn & \multirow{2}{*}{$\begin{array}{l}\text { - } \mathrm{CuZn} \text { and } \mathrm{CuAl}_{2} \text { had some effect in the } \\
\text { mechanical properties of the Al-Cu joint. }\end{array}$} & \multirow[t]{2}{*}{ - No defects were found. } \\
\hline & & $\mathrm{CuAl}_{2}$ & & \\
\hline
\end{tabular}


intermetallic compound formation has no effect on the corrosion properties; however, welding parameters and base metal properties have a significant effect on the corrosion properties in the weld metal.

\section{Comparison}

A comparison between friction stir welding, laser welding and brazing in welding of $\mathrm{Al}(1060)$ and pure $\mathrm{Cu}$ is shown in Table 2.

\section{Discussion and conclusions}

The power generation industry and many other industries require effective joining of $\mathrm{Al}$ and $\mathrm{Cu}$, without defect formation and with suitable properties in the joint, to enable applications in different service conditions. For the welding of dissimilar metals, solid-state welding is usually preferred to fusion welding processes because differences in the melting of the metals together, with significant differences in the chemical, physical and mechanical properties, result in the formation of brittle intermetallic compounds and defects in the weld metal. Various studies have shown that joints made with solid-state welding have better properties than joints made with conventional welding processes.

Weld properties are defined by the factors determining the microstructural formation in the weld metal, which in turn determines the weld strength. Some of the factors concerned have to be considered at the initial joint design stage, before the welding process, to avoid discontinuities. For instance, the thermal properties of $\mathrm{Al}$ and $\mathrm{Cu}$ have to be considered because they are very important factors for good bonding between the metals and avoidance of defect formation. The factors that influence the $\mathrm{Al}-\mathrm{Cu}$ weld properties vary depending on the welding process and these factors have to be considered in order to fabricate a successful dissimilar $\mathrm{Al}-\mathrm{Cu}$ joint.

The intermetallic compounds formed in the interface zone of $\mathrm{Al}-\mathrm{Cu}$ have both favourable effects and detrimental effects on the joints. Moreover, some of the intermetallic compound phases formed have been found to be the same in both fusion welding and solid-state welding. The characteristics of these intermetallic compounds vary according to the location of the phase formed. Definitive reasons for defective intermetallic compound formation are not known. More researches are therefore needed to investigate reduction in brittle intermetallic compound formation, the factors promoting the formation of such compounds and their effect on weld properties. There is moreover a need for a significant research on dissimilar welding of $\mathrm{Al}$ with $\mathrm{Cu}$ to optimise manufacture of defect-free $\mathrm{Al}-\mathrm{Cu}$ joints without brittle intermetallic compounds and thus enable industrial-scale production.

\section{Competing interests}

The authors declared that they have no competing interests.

\section{Author's contributions}

All the authors have drafted the manuscript. All authors read, analyzed, and approved the final manuscript.

Received: 12 March 2015 Accepted: 25 June 2015

Published online: 11 July 2015

\section{References}

Abdollah-zadeh, A, Saeid, T, \& Sazgari, B. (2008). Microstructural and mechanical properties of friction stir welded aluminum/copper lap joints. Journal of Alloys and Compounds, 460(1-2), 535-538.

Acarer, M. (2012). Electrical, corrosion, and mechanical properties of aluminum-copper joints produced by explosive welding. Journal of Materials Engineering and Performance, 21(11), 2375-2379.

Akinlabi, ET, Andrews, A, \& Akinlabi, SA. (2014). Effects of processing parameters on corrosion properties of dissimilar friction stir welds of aluminium and copper. Transactions of Nonferrous Metals Society of China, 14(5), 1323-1330.

Balasundaram, R, Vikas, KP, Bhole, SD, \& Chen, D. (2014). Effect of zinc interlayer on ultrasonic spot welded aluminum-to-copper joints. Materials Science \& Engineering A, 607, 277-286.

Berlanga-Labari, C, Albístur-Goñi, A, Balerdi-Azpilicueta, P, Gutiérrez-Peinado, M, \& Ferńandez Carrasquilla, J. (2011). Study and selection of the most appropriate filler materials for an Al/Cu brazing joint in cooling circuits. Materials and Manufacturing Processes, 26(2), 236-241.

Bisadi, H, Tavakoli, A, Sangsaraki, MT, \& Sangsaraki, KT. (2013). The influences of rotational and welding speeds on microstructures and mechanical properties of friction stir welded Al5083 and commercially pure copper sheets lap joints. Materials \& Design, 43, 80-88.

Braunović, M, \& Alexandrov, NG. (1994). Intermetallic compounds at aluminum-to-copper electrical interfaces: effect of temperature and electric current. IEEE Transactions on Components, Packaging, and Manufacturing Technology, 17(1), 78-85.

Feng, J, Songbai, X, \& Wei, D. (2012a). Reliability studies of Cu/Al joints brazed with Zn-Al-Ce filler metals. Materials \& Design, 42, 156-163.

Feng, J, Song-bai, X, Ji-yuan, L, Yin-bin, L, \& Shui-qing, W. (2012b). Microstructure and properties of Cu/Al joints brazed with Zn-Al filler metals. Transactions of Nonferrous Metals Society of China, 22(2), 281-287.

Feng, J, Songbai, X, \& Wei, D. (2013). Effects of Ti on the brazability of Zn-22Al-xTi filler metals as well as properties of Cu/Al brazing joints. Rare Metal Materials and Engineering, 42(12), 2453-2457.

Feng, J, \& Xue, S. (2013). Growth behaviors of intermetallic compound layers in $\mathrm{Cu} / \mathrm{Al}$ joints brazed with $\mathrm{Zn}-22 \mathrm{Al}$ and $\mathrm{Zn}-22 \mathrm{Al}-0.05 \mathrm{Ce}$ filler metals. Materials and Design, Volume, 51, 907-915.

Francis R., 2000. Bimetallic corrosion. [Online] Available at: http:// www.npl.co.uk/upload/pdf/bimetallic_20071105114556.pdf. [Accessed 14 June 2014].

Galvão, I, João Carlos, O, Loureiro, A, \& Rodrigues, DM. (2012). Formation and distribution of brittle structures in friction stir welding of aluminium and copper: Influence of shoulder geometry. Intermetallics, 22, 122-128.

Galvão, I, Leal, R, Loureiro, A J R \& Rodrigues, D M, (2010). Material flow in heterogeneous friction stir welding of aluminium and copper thin sheets. Science and Technology of Welding and Joining, 15(8), pp. 654-660.

Hailat, MM, Mian, A, Chaudhury, Z A, Newaz, G M, Patwa, R \& Herfurth, H J. (2012). Laser micro-welding of aluminum and copper with and without tin foil alloy. Microsystem Technologies, 18(1), 103-112.

Hayes, M, Thornton, C E, Ibarra, S J., McMaster, J A, \& Walter, C E. (2001). Clad and Dissimilar metal. In: Welding handbook Volume 4: Materials and Applications. s.l.:American Welding Society, pp. 394-450.

Huseyin, U, Claudio Dalle, D, Argagnotto, A, Ghidini, T, \& Gambaro, C. (2005). Friction stir welding of dissimilar Al 6013-T4 to X5CrNi18-10 stainless steel [J]. Materials and Design, 26(1), 41-46.

Ihor, M, \& Schmidt, M. (2006). Laser micro welding of copper and aluminum. Proceedings of the SPIE, 6107, 28-33.

Jariyaboon, M, Davenport, A J, Ambat, R, Connolly, B J, Williams, S W, \& Price, D A. (2007). The effect of welding parameters on the corrosion behaviour of friction stir welded AA2024-T351. Corrosion Science, 49(2), 877-909. 
Joseph, RD. (2006). Corrosion of weldments. In RD Joseph (Ed.), Corrosion of dissimilar metal weldments. s.I. (pp. 169-175). USA: ASM International.

Klauke, 2012. Klauke A Textron Comapany. [Online] Available at: http:// www.klauke.com/en/electrical/technical-reports/accurately-connectingcopper-and-aluminium/. [Accessed 2110 2014].

Krishnan, S, Murty, BS, \& Kalvala, PR. (2009). Effect of processing parameters on the corrosion behaviour of friction stir processed AA 2219 aluminum alloy. Solid State Sciences, 11(4), 907-917.

Lawrence, M, Ying, L, Flores, R D, Elizabeth, A T, \& McClure, J C. (1998). Intercalation vortices and related microstructural features in the friction-stir welding of dissimilar metals. Materials Research Innovations, 2(3), 150-163.

Lee, T, Choi, W, Tu, K, Jang, J, Kuo, S M, Lin, J, Frear, D R, Zeng, K, \& Kivilahti, J K. (2002). Morphology, kinetics, and thermodynamics of solid-state aging of eutectic $\mathrm{SnPb}$ and Pb-free solders ( $\mathrm{Sn}-3.5 \mathrm{Ag}, \mathrm{Sn}-3.8 \mathrm{Ag}-0.7 \mathrm{Cu}$ and $\mathrm{Sn}-0.7 \mathrm{Cu}$ ) on Cu. Journal of Materials Research, 17(2), 291-301.

Leonardo, RG, Wislei, RO, \& Amauri, G. (2011). The effect of cooling rate on the dendritic spacing and morphology of $\mathrm{Ag} 3 \mathrm{Sn}$ intermetallic particles of a SnAg solder alloy. Materials \& Design, 32(5), 3008-3012.

Lin, S, Song, J, Yang, C, \& Ma, G. (2009). Microstructure analysis of interfacial layer with tungsten inert gas welding-brazing joint of aluminum alloy/ stainless steel [J]. Acta Metallurgica Sinica, 45(10), 1211-1216.

Liu, P, Shi, Q, Wang, W, Wang, X, \& Zhang, Z. (2008). Microstructure and XRD analysis of FSW joints for copper T2/aluminium 5 A06 dissimilar materials. Materials Letters, 62(25), 4106-4108.

Li, X-W, Zhang, D-T, Qiu, C, \& Zhang, W. (2012). Microstructure and mechanical properties of dissimilar pure copper/1350 aluminum alloy butt joints by friction stir welding. Transactions of Nonferrous Metals Society of China, 22(6), 1298-1306.

Lloyd AC, 1957. Aluminum dissimilar metal joint and method of making same. Unites state, Patent No. 2790656

Mai, TA, \& Spowage, AC. (2004). Characterisation of dissimilar joints in laser welding of steel-kovar, copper-steel and copper-aluminium. Materials Science and Engineering A, 374(1-2), 224-233.

Mubiayi, M. P. \& Akinlabi, E. T., 2013. Friction stir welding of dissimilar materials between aluminium alloys and copper - An overview. Lecture Notes in Engineering and Computer Science, Volume 3, pp. 1990-1996.

Nicholas, MG, \& Old, C. (1979). Liquid metal embrittlement. Journal of Materials Science, 14(1), 1-18.

Ochi, H, Ogawa, K, Yamamoto, Y, Kawai, G, \& Sawai, T. (2004). The formation of intermetallic compounds in aluminium alloy to copper friction-welded joints and their effect on joint efficiency. Welding International, 18(7), 516-523.

Ouyang, J, Yarrapareddy, E, \& Kovačević, R. (2006). Microstructural evolution in the friction stir welded 6061 aluminum alloy (T6-temper condition) to copper. Journal of Materials Processing Technology, 172(1), 110-122.

Pang, J, Tan, K, Shi, X, \& Wang, Z. (2001). Microstructure and intermetallic growth effects on shear and fatigue strength of solder joints subjected to thermal cycling aging. Materials Science and Engineering A, 307(1-2), 42-50.

Posinasetti, P, \& Prasad, KY. (2005). Meeting challenges in welding of aluminium alloys through pulse gas metal arc welding. Journal of Materials Processing Technology, 164-165, 1106-1112.

Sahin, M. (2009). Joining of aluminium and copper materials with friction welding. The International Journal of Advanced Manufacturing Technology, 49(5-8), 527-534

Sarvghad-Moghaddam, M, Parvizi, R., Davoodi, A., Haddad-Sabzevar, M. \& Imani, A. (2014). Establishing a correlation between interfacial microstructures and corrosion initiation sites in Al/Cu joints by SEM-EDS and AFM-SKPFM. Corrosion Science, Volume, 79, 148-158.

Solacity, 2011. Solacity Inc. Reliable Green power. [Online] Available at: http://www.solacity.com/docs/polyphaser/dissimilar\%20metals\%20may\% 20take\%20away\%20your\%20protection.pdf. [Accessed 295 2014].

Solchenbach, T, Plapper, P, \& Cai, W. (2014). Electrical performance of laser braze-welded aluminum-copper interconnects. Journal of Manufacturing Processes, 16(2), 183-189.

Song-bai, X, Jian, D, Xiao-chun, L, \& Yi-yu, Q. (2003). Brazing technology of LY12 Al-alloy at middle temperature [J]. Transactions of the China Welding Institution, 24(3), 21-23.

Song, J, Lan, GF, Lui, T, \& Chen, L. (2003). Microstructure and tensile

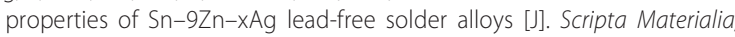
48(8), 1047-1051.
Sujin, L, Tatsuo, N, Yousuke, K, \& Seiji, K. (2014). Effect of welding speed on microstructural and mechanical properties of laser lap weld joints in dissimilar Al and Cu sheets. Science and Technology of Welding and Joining, 19(2), 111-118

Sun, Z, \& Karppi, R. (1996). The application of electron beam welding for the joining of dissimilar metals: an overview. Journal of Materials Processing Technology, 59(3), 257-267.

Sun, Z, \& Moisio, T. (1994). Melting ratio in laser welding of dissimilar metals. Journal of Materials Science Letters, 13(13), 980-982.

Takehiko, W. Yanagisawa, A., Konuma, S., Yoneda, A. \& Ohashi, O., 1999 (Online-2010). Ultrasonic welding of Al-Cu and Al-SUS304. Study of ultrasonic welding of dissimilar metals (1st Report) Welding International, 13(11), pp. 875-886

Tan, C-W, Jiang, Z., Li, L., Chen, Y. \& Chen, X. (2013). Microstructural evolution and mechanical properties of dissimilar Al-Cu joint produced by friction stir welding. Materials and Design, 51, 466-473.

Tohid, S, Abdollah-zadeh, A, \& Sazgari, B. (2010). Weldability and mechanical properties of dissimilar aluminum-copper lap joints made by friction stir welding. Journal of Alloys and Compounds, 490(1-2), 652-655.

Weigl, M, Albert, F, \& Schmidt, M. (2011). Enhancing the ductility of laser-welded copper-aluminum connections by using adapted filler materials. Physics Procedia, 12(Part B), 332-338.

Weigl, M, \& Schmidt, M. (2009). Modulated laser spot welding of dissimilar copper-aluminum connections. Germany: Karlsruhe, s.n.

Wonbae, L, Kuek-Saeng, B, \& Seung-Boo, J. (2005). Effects of intermetallic compound on the electrical and mechanical properties of friction welded Cu/Al bimetallic joints during annealing. Journal of Alloys and Compounds, 390(1-2), 212-219.

Xia, C, Li, Y, Puchkov, U A, Gerasimov, S A, \& Wang, J. (2008). Microstructure and phase constitution near the interface of $\mathrm{Cu} / \mathrm{Al}$ vacuum brazing using $\mathrm{Al}-\mathrm{Si}$ filler metal. Vacuum, 82(8), 799-804.

Xiao, Y, Hongjun, J, Li, M, \& Jongmyung, K. (2013). Ultrasound-assisted brazing of Cu/Al dissimilar metals using a Zn-3Al filler metal. Materials \& Design, 52, 740-747.

Xue, P, Xiao, B, Ni, D, \& Ma, Z. (2010). Enhanced mechanical properties of friction stir welded dissimilar Al-Cu joint by intermetallic compounds. Materials Science and Engineering: A, 527(21-22), 5723-5727.

Yan, X, Liu, S, Long, W, Huang, J, Zhang, L, \& Chen, Y. (2013). The effect of homogenization treatment on microstructure and properties of ZnAl15 solder. Materials \& Design, 45, 440-445.

Yong, GK, Hidetoshi, F, Tsumura, T, Toru, K, \& Kazuhiro, N. (2006). Three defect types in friction stir welding of aluminum die casting alloy. Materials Science and Engineering: $A, 415(1-2), 250-254$

Zhao, Y, Li, D, \& Zhang, Y. (2013). Effect of welding energy on interface zone of $\mathrm{Al}-\mathrm{Cu}$ ultrasonic welded joint. Science and Technology of Welding and Joining, 18(4), 354-360

Zuo, D, Hu, S, Shen, J, \& Xue, Z. (2014). Intermediate layer characterization and fracture behavior of laser-welded copper/aluminum metal joints. Materials and Design, 58, 357-362.

\section{Submit your manuscript to a SpringerOpen ${ }^{\circ}$ journal and benefit from:}

- Convenient online submission

Rigorous peer review

- Immediate publication on acceptance

- Open access: articles freely available online

- High visibility within the field

- Retaining the copyright to your article

Submit your next manuscript at $>$ springeropen.com 